\title{
Implementation of Diversion of Children Using Narcotics and Victims in the Concept of Restorative Justice
}

\author{
Eko Adi Setiawan ${ }^{1}$, Zudan Arief Fakrulloh ${ }^{2}$ \\ \{adieko42@gmail.com ${ }^{1}$,cclsis@yahoo.com ${ }^{2}$ \} \\ Universitas Borobudur, Jakarta, Indonesia ${ }^{1,2}$
}

\begin{abstract}
Drug abuse becomes a ruthless crime because if we trace it not only adults who are entangled in this case, children also do not escape the bondage of narcotics. This study aims to describe the imposition of criminal law and diversion on children who use drugs and victims of narcotics crimes. The library method is used to examine this case which is also qualitative research. This study found that imposing a rehabilitation sentence, either non-institutional or institutional treatment of children to maintain the rights of children. The conclusion is that narcotics crimes against children, both users, and victims, often trap children in a vicious narcotics circle. There needs to be a particular application in networks involving children in the distribution of narcotics, an international crime. Implementing this diversion can be a bridge in court rulings against children engaged in narcotics trafficking networks.
\end{abstract}

Keywords: Diversion; Children Using Narcotics; Victim; Restorative Justice

\section{Introduction}

Regulations related to Narcotics in Indonesia are The Republic of Indonesia's Law No. 35 of 2009 on Narcotics regulates the use of narcotics. The law oversees the levying of criminal penalties against drug users. Narcotics, as indicated in Article 127, users can be sentenced to a minimum of 4 years to 20 years in prison [1]. The punishment of minors who use drugs is Indonesia is governed by Art 81 of the Legislation of Indonesia Number 11 of 2012 governing the Immature Court System. According to this law, a child who uses narcotics can be sentenced to imprisonment for a period of time equal to half of the maximum penalty for adults, usually less than a year [2]. The Constitution of the Republic of Indonesia No. 11 of 2012 on the Adolescent Justice System also governs diversio. Diversion is a method that moves the resolution of children's cases from the criminal justice system to a system that is not based on the criminal justice system. Before the youngster enters the criminal court system, diversionary efforts will be made.

Children's involvement with narcotics does not only become users. They are also used as couriers. An example is the case of a young man with the initials AR who is still 17 years old. The suspect was arrested by the Bandung Police Narcotics Investigation Unit (Satres) in early 2018 for being a drug courier for methamphetamine. The suspect was arrested at Cipicung 
Orchid Gang, Pasirwangi Village, Ujung Berung, Bandung City. Officers obtained evidence from the suspect in a clear plastic clip containing crystal methamphetamine weighing 14.92 grams. Officers also searched the suspect's residence and found evidence of methamphetamine with a gross of 50.71 grams and a digital scale. Because the suspect is still a minor, he is subject to Article 114 paragraph (2) of the Republic of Indonesia Law 35 of 2009 concerning Narcotics, in conjunction with Article 112 paragraph (2) of the Republic of Indonesia Law 35 of 2009 concerning Juvenile Justice System, with a maximum penalty of 20 years, suspects were only deposited in the Special Child Correctional Institution (LPKA) [3].

Drug abuse can be classified as a crime in the absence of a victim. Victimless crime is defined as a crime that does not result in any victims, yet the offender is the victim. If the defendant is a kid, He is subject to the best interests of the kid premise. Children in legal trouble, as they are now termed, cannot be sentenced to the death penalty, life in prison, or other forms of punishment that are incompatible with the notion of the child's best interests. Various indications show that narcotics crime is an extraordinary crime. The meaning is a crime that has a significant and multi-dimensional impact on social, cultural, economic, and political and the enormity of the adverse effects caused by narcotics crime. For this reason, unusual punishment would be relevant to accompany the crime model with extraordinary characteristics, which nowadays is increasingly spreading throughout the world as a transnational crime. There happens because of demand and supply [4].

Indonesia has become one of the target countries for drug trafficking controlled by international networks. The results of BNN's detection are 72 global networks that run the drug business. Currently, his party is exploring whether one web and another are related or not. So this network is always working and taking advantage of all existing weaknesses, both monitoring and our equipment systems, including our x-ray machines. After everything is mastered, then they launch on the field. Usually, the sea route is one of the selected doors. Then, weak ports are used, such as the Malacca strait, where many ships are crossing back and forth, but the supervision is few and difficult. They take advantage of it, so BNN needs to cooperate with parties related to this network.

Will address key issues in criminal case resolution, such as: first, responses of a judicial system for failing to just provide possibilities, particularly for survivors (court system that empowers persons); second, resolving conflicts, especially between perpetrators and victims and the community (removing competition from them); and third, the fact that the feeling of powerlessness experienced as a result of a crime must be overcome (criminal justice system that empowers individuals) (to achieve reparation). The use of narcotics by children is not just a law enforcement problem. The problem is complex and multi-faceted. Therefore, the issue of drug use should not be viewed as a mere legal issue. Based on the evidence, many aspects must be studied and used as primary considerations, especially drug users' health and social elements. In the context of children who use narcotics, the state must also look at children's best interests, vulnerabilities, and assumptions about the immaturity of children's thinking as considerations in making narcotics policies [5].

Meanwhile, in the criminal context, because The Narcotics Law No. 35 of 2009 continues to prohibit narcotics and children who use them use drugs have the right to get equal treatment before the law. The status of a child as a narcotics user should not be used as a basis for discriminatory treatment of a child who uses narcotics before the law. Therefore, the state must ensure the availability of access to an honest and fair juvenile criminal justice without differentiating the treatment or process for children who use narcotics. However, this does not mean that affirmative action cannot be taken in law enforcement. 
Affirmative action can be taken for vulnerable groups of children to ensure that children's rights are respected. There is a lot of value in applying it to issues involving children drug users who conflict with the law, for example, diversion for children who use narcotics or providing medical rehabilitation services in prison for children who use narcotics who commit criminal acts. The child's best One of the four basic concepts in implementing the Convention on the Rights of the Child is the principle of interest. The state's top priority must be the child's best interests in deciding policies, laws, court decisions, and other government actions related to children.

The concept of children's best interests cannot be uniformed, meaning that It's possible that the best interests of children who use opioids differ from those of children with disabilities. As a result, the concept of the child's best interests comes into play must be flexible and adaptable under certain conditions. This concept must be adapted and defined individually according to the needs or particular situation of the child. Even if the state does not have specific procedures regarding implementing the best interests of children who use narcotics, the general standards included in the International Covenant on Civil and Political Rights for Children and other international legal instruments can be used to meet the best interests of children. Meanwhile, for children who use narcotics, their best interests must be realized when accessing health services and when forced to face the law.

Children who use narcotics tend to become addicted to certain substances. Therefore a health assessment is needed from the beginning of the investigation process to see to what extent the addiction interferes with the child's health condition. If the level of addiction requires further treatment, the child who uses narcotics should be immediately referred to health services such as a hospital or rehabilitation center. So that detention and imprisonment can be avoided. The approach to preventing the use of narcotics in children must also consider the child's best interests.

Control and prevention of crime, especially narcotics crimes by police officers, have a very central role and at the same time become a determinant of whether to proceed to the judicial process or by other informal actions. The authority in determining whether a child will be resolved through a formal to informal process. In this case, the police apparatus has been equipped with a legal instrument in dealing with Criminal crimes committed by children called diversion. In district courts, diversion efforts must be made during the investigation, prosecution, and examination of children's cases. This is also spelled out in Article 7 of Law No. 11 of 2012 on the Juvenile Criminal Justice System, which states:

a. Diversion must be sought Children's cases are investigated, prosecuted, and examined at the district court level.

b. The If a criminal conduct is committed, the diversion described in paragraph (1) is carried out:

1. Facing a sentence of less than seven (seven) years in prison; and

2. It is not a repetition of a crime.

Because of this, law enforcement officers, especially the police, should be the initiators and facilitators of handling youngsters who have run afoul of the law by urging all parties involved, including the culprits, victims, their parents, the local community, or the school, to attend a meeting to discuss the situation the process. Settlement using a restorative justice approach. However, recently there has been an increasing number of drug abuse by children. 


\section{Methodology}

The method is understood as a way or way to think about and examine something according to a specific plan, concerning how it works to understand the object that is the target of the science involved. Research is a methodologically, systematically, and consistently carried out scientific activity involving analysis and construction. Because research attempts to disclose the truth, It is a critical instrument in the methodical advancement of technology. methodological, and consistent manner by conducting analysis and construction. In the context of this research, the research method is understood as a way of working in scientific activities related to the study and legal structure of embezzlement in the office. Some things that need to be explained related to the research approach, types of research data, data collection, data analysis, and so on are described.

Legal research generally distinguishes between data gathered from the general public and library materials Primary data (or fundamental data) is gathered directly from the community, Secondary data, on the other hand, is often gathered through library materials. Because the data is in a library, this research is classified as library research or materials needed in completing the analysis come from the literature in the form of journal books, literature, books, research reports, and so on related to the problems studied, namely (1) criminal policies for drug crimes by children, and (2) drug crimes by children in the perspective of the Criminal Code and the Draft Criminal Code (KUHP and RKUHP).

\section{Results and Discussion}

\subsection{The Policy of Imposing Criminal Penalties on Children Who Use Narcotics in Indonesia}

Based According to the Law of the Republic of Indonesia No. 35 of 2009 on Narcotics, Psychotropics, and Other Addictive Substances, narcotics offences are subject to harsh penalties, including the potential of the offender receiving a death sentence in addition to prison and fines. [6] Article 127 of the Law of the Republic of Indonesia Number 35 of 2009 Concerning Narcotics contains criminal threats for narcotics abusers for adults which reads:

a. Any Abusers:

1. Narcotics Category I for oneself shall be sentenced to a maximum imprisonment of 4 (four) years;

2. Narcotics Category II for oneself shall be sentenced to a maximum imprisonment of 2 (two) years; and

3. Narcotics Category III for oneself shall be sentenced to a maximum imprisonment of 1 (one) year.

b. When deciding the case referred to in paragraph (1), the court must take into account the provisions of Articles 54, 55, and 103.

c. Assume that the abuser (as defined in paragraph 1) can be demonstrated to be a narcotics abuse victim. In that instance, the abuser is required to go through medical and social rehabilitation.

The Legislation of the Republic of Indonesia No. 11 of 2012 on the Juvenile Justice System establishes the groundwork for drugs use by children. Because the Legislation of the Republic of Indonesia Number 11 of 2012 on the Adolescent Judicial System serves as the foundation for judges in the application of criminal sanctions for the resolution of juvenile 
delinquency cases as a special provision applied to children based on the principle of lex specialista legi generalis, it disregards the criminal provisions of the Law of the Republic of Indonesia Number 35 of 2009 on Narcotics and imposes separate sanctions.

The Adolescent Criminal System is defined in Article 1 point 1 of Law No. 11 of 2012, which specifies that it has a number of qualities. Investigations carried out by Investigators, namely RI state police officers as referred to by Law of the Republic of Indonesia Number 2 of 2002 concerning the Indonesian National Police, Prosecutors carried out by Public Prosecutors, namely Prosecutors as referred to by Law of the Republic of Indonesia Number 16 the Year 2004 concerning the Prosecutor's Office of the Republic of Indonesia, The District Court, as the Court of First Instance, and the High Court, as the Court of Appeal: a. Community Advisors, b. Professional Social Workers, and c. Social Welfare Workers, as defined in Article 63 of the Republic of Indonesia Number 11 of 2012 concerning the Child Criminal Justice System, and as defined in Article 50 and Article 51 paragraph (1) of the Republic of Indonesia Number 2 of 1986 concerning General Courts.[7]

The elements or modules of the Youth Judicial System are interwoven in a structure of interconnection in carrying out their obligations and powers, as defined in or following the Juvenile Justice Procedural Law, specifically Law Number 11 of the Republic of Indonesia in 2012. The judicial system, as per Muladi, is a judicial system that employs material criminal law, formal criminal law, and criminal law enforcement.This institution, on the other hand, must be seen in the context of society. 112. Too formal nature, based exclusively on legal certainty, will result in disaster in the shape of child injustice [8]. The Act of the Republic of Indonesia No. 11 of 2012 on the Adolescent Judicial System contains a number of instructions, including those in Articles 2 and 5. According to Article 2 and its interpretations, the adolescent criminal law is built on the following principles:

1. Protection encompasses both direct and indirect efforts aimed at preventing physical and psychological harm to children.

2. Justice, in the sense that every kid's case settlement represents a sense of justice for the child.

3. Nondiscrimination, i.e., no discrimination based on ethnicity, religion, color, class, gender, ethnicity, culture, and language, children's legal status, birth order, or physical or mental condition.

4. The continuity of the child's growth and development must always be considered when making decisions in the child's best interests..

5. Respect for children's viewpoints, including their rights to have interests and voice them in decision-making.

6. Children's survival and development are the most basic human rights that the state, government, community, family, and parents safeguard.

7. The existence of coaching, that is, activities aimed at enhancing the quality, purity to God Almighty, intellect, attitude and conduct, training, skills, professionalism, and physical and spiritual health of children, both within and outside the criminal justice system. Guidance refers to the provision of advice to correctional clients in order to enhance their level of righteousness to God Almighty, intellectual, attitude and behavior, skills training, professional, physical, and spiritual health. According to Article 5 of Law No. 11 of 2012 of the Republic of Indonesia on the Juvenile Criminal Justice System:

a. The Juvenile A restorative justice strategy must be prioritized in the criminal justice system.

b. Unless otherwise specified in this law, the Juvenile Criminal Justice System includes criminal investigations and prosecutions of children conducted in accordance with the 
provisions of laws and regulations, child trials conducted by courts within the general judiciary, and guidance, guidance, supervision, and assistance provided to children while committing a crime or action. After an offense or movement in the Juvenile Criminal Justice System, letters a and b must be sought for diversion, as specified in paragraph.

Children who are involved in the law, as well as every child involved in the criminal justice process, have the right to be treated humanely, according to the Law of the Republic of Indonesia No. 11 of 2012 on the Juvenile Criminal Justice System, with the goal of creating a court that truly protects the best interests of children in conflict. Law. The legislation on the Justice System Against Children covers, among other things, the following essential issues:

The Law on the Youth Justice System defines a child as someone who is Twelve years old but not yet Eighteen, and divides children who commit crimes into three categories. Children who commit criminal acts (child perpetrators) (Article 1 number 3 of the Law of the Republic of Indonesia Number 11 of 2012 concerning the Juvenile Criminal Justice System), Children who are victims of criminal acts (child victims) (Article 1 number 4 of the Law of the Republic of Indonesia Number 11 of 2012 concerning the Child Criminal Justice System), Children who are witnesses to criminal acts (Article 1 Section 5 of the Republic of Indonesia's Law No. 11 of 2012 on the Criminal Justice System for Children) (child witnesses) (Article 1 point 5 of the Law of the Republic of Indonesia Number 11 of 2012 concerning the Juvenile Criminal Justice System).

Sanctions are put in place. For criminals under the age of 14, Article 69 paragraph (2) of the Law of the Republic of Indonesia No. 11 of 2012 concerning the Juvenile Criminal Justice System states that a juvenile offender might face two types of consequences: action sanctions and criminal sanctions. The Sanctions for activities that can be imposed on children 117 are set out in article 82 of the Law of the Republic of Indonesia Number 11 of 2012 governing the Juvenile Criminal Justice System. Please return to your parents or guardians. Transfer to someone, treatment in a mental institution, LPSK treatment Obligation to attend governmentsponsored or private-sector-sponsored formal education and training Due to a criminal act, a driver's license may be revoked or repaired.

According to Article 71 of the Law of the Republic of Indonesia, Number 11 of 2012, concerning the Juvenile Criminal Justice System, the criminal sanctions that can be imposed on children are the principal and additional penalties. If it is detailed again, the punishment is a Principal Crime, and an Additional Criminal is determined as follows:

a. Warnings, criminal conditions with conditions (coaching outside the institution, community service, supervision), employment training, institutional coaching, and incarceration are the most common penalties for youngsters.

b. Additional punishments include the deprivation of profits acquired through illegal behavior, as well as the execution of customary responsibilities.

According to Law No. 11 of 2012 concerning the Juvenile Criminal Justice System of the Republic of Indonesia, research scientists, society advisors, and professional social workers may decide to palm over a kids under the age of 12 (twelve) years if he commits or is suspected of committing a criminal act. To families for a maximum of six months or to involve them in education, coaching, and mentoring programs at government entities or LPSK in social welfare organizations at the national and regional levels.

According to Law No. 11 of 2012 concerning the Juvenile Criminal Justice System of the Republic of Indonesia, investigators, community counselors, and professional social workers may decide to hand over a child under the age of 12 (twelve) years if he commits or is suspected of committing a criminal act. It is unbiased and objective to provide education, 
coaching, and mentoring to parents/guardians or to involve them in educational, coaching, and mentoring programs at government agencies or LPSK in social welfare agencies, both at the national and regional levels, for a maximum of six months. In a public closed trial, the defendant's identity is not revealed, he or she receives assistance from parents/guardians and others whom the children trust, obtains social advocacy, a private life, gains accessibility, particularly for disabled children, receives education, receives health services, and obtains other rights in accordance with the law [9].

In article 4 According to Law No. 11 of 2012 of the Republic of Indonesia on the Juvenile Criminal Justice System, children who are suffering a criminal period are entitled to remission in exchange for a reduction in the illegal period, assimilation, and rehabilitation, parole, leave before release, conditional leave, other rights following with statutory regulations. Article 32 Paragraph (2) of According to the Law of the Republic of Indonesia Number 11 of 2012 on the Juvenile Criminal Justice System, a child can only be detained if he or she is 14 (fourteen) years old or is suspected of committing a crime that carries a sentence of 7 (seven) years or more. If the detention period is as long as mentioned above has ended, the child must be released from custody by law.

The Juvenile Criminal Justice System Law of the Republic of Indonesia No. 11 of 2012 permits minors who have committed criminal actions to obtain legal assistance regardless of the type of violation they have committed. Children have the right to obtain legal assistance at any stage of the investigation, investigation, prosecution, or court appearance (Article 23 of the Law of the Republic of Indonesia Number 11 of 2012 concerning the Juvenile Criminal Justice System). Children who have not completed a sentence at the Special Child Development Institution (LPKA) and have reached the age of 18 are transferred to a youth correctional institution, and certain blocks are provided, according to Article 86 paragraph (1) of the Law of the Republic of Indonesia Number 11 of 2012 concerning the Juvenile Criminal Justice System. Those between the ages of 18 and 21 years old.

Concerning the severity of the punishment that can be imposed on a child, it is necessary to know, the threat of imprisonment for a child who commits a crime is half of the maximum imprisonment for an adult as regulated in Article 81 paragraph (2) of the Law of the Republic of Indonesia. Number 11 of 2012 concerning the Juvenile Criminal Justice System:

The maximum sentence of imprisonment that can be imposed on a kid is $1 / 2$ (one half) of the maximum sentence of imprisonment that can be imposed on an adult. Since the enactment Diversion is a phrase used in the Republic of Indonesia Number 11 of 2012 regulating the Juvenile Criminal Justice System. Diversion is a method that moves the resolution of children's cases from the criminal justice system to a system that is not based on the criminal justice system. Diversion is only used if the offence committed is punishable by a sentence of less than seven (seven) years in jail and is not a repeat offense.

According to the concept Because of the nature of children, discipline is used to re-educate and improve them rather than to punish them. Avoiding child exploitation and violence would be desirable if redirected and ineffective if disciplined. Diversion also aims to shield children from the negative consequences of criminal participation while also ensuring their physical and cognitive development. Judges in deciding cases The provisions of the Law of the Republic of Indonesia Number 11 of 2012 regulating the Juvenile Criminal Justice System also apply to children who commit narcotics offences. Applying criminal sanctions for children often creates dilemmatic problems, both juridically, sociologically, and philosophically. This is, of course, very different from the purpose of the criminal. Juridically, children who abuse narcotics are qualified as criminals but conceptually. 
Narcotics abuse is qualified as a crime without a victim, which means that the victim of the crime is the perpetrator himself, so in the case of narcotics abuse, the victim (offense) is the perpetrator. Conceptually, children who abuse narcotics, apart from their qualifications as perpetrators, are also victims. When a judge punishes a youngster for drugs abuse, the child is considered a narcotics abuser. The defendant will be returned to his or her parents under Article 127 paragraph (1) of the Law of the Republic of Indonesia Number 35 of 2009 concerning Narcotics, Article 24 paragraph (1) letter an of the Law Republic of Indonesia Number 3 of 1997 concerning Juvenile Court, and other relevant laws and regulations.

In principle, narcotics abusers for themselves are guaranteed rehabilitation. One of the most effective interventions for children who are drug abusers is rehabilitation. Medical rehabilitation and social rehabilitation are the two types of rehabilitation. Medical rehabilitation is a set of integrated therapy activities aimed at improving a kid's physical state, as well as that of the child victim and witness. Social rehabilitation is a process of integrating physical, mental, and social healing exercises so that children, child victims, and child witnesses can resume their social roles society.

Based on the two rehabilitation models above, children who are perpetrators of narcotics abuse need to participate in therapy and rehabilitation programs in various forms. Inpatient is inpatient treatment in a particular hospital (Drug Dependence Hospital), Mental Hospital, or in one part (unit) of a General Hospital. This therapy is often called primary therapy (primary treatment). Therapy can last up to 4-6 weeks or maybe more, depending on the type of service available, even perhaps a rehabilitation program of up to 2 years. Outpatients are carried out in hospitals (special and general), outpatient sections, clinics, and puskesmas, usually lasting ten weeks for 2-3 hours, 2-4 times a week. In comparison to inpatient programs, outpatient programs feature fewer program components. Because medicines are more easily accessible to patients, random urine testing is an important aspect of the process.

Several types of rehabilitation facilities are social rehabilitation, spiritual rehabilitation, and psychosocial rehabilitation. Some are managed by the government or private. Some of them apply the concept of Therapeutic Community (TC). Half Way House is a Mentoring house as a transitional place between the hospital and going home. This facility has not yet been developed in Indonesia. Here 10-20 clients live together with supervision and home care responsibilities: shopping, cooking, cleaning, and washing clothes. They go to school or work part-time, but there is still a recovery program. This type of treatment is suitable for addicts who have not made much progress on primary therapy, those who do not have access to a hospital/rehabilitation therapy center, and those who have not returned home due to unresolved family issues or a bad environment.

Community-Based Therapy and Rehabilitation is an outpatient program (although it can have inpatient facilities) as a model developed to reach and help addicts in the community. The principle of this program is a "self-help group," which is a group that helps each other by using trained local community members. Not all cases of narcotics abuse can get rehabilitation. The effectiveness of The use of jail as a tactic for achieving the goal of punishment is still up for dispute. This means that if a criminal is condemned to prison, there is no guarantee that he will automatically return to being a good and law-abiding member of society. Imprisonment has a very negative impact on convicts, especially child convicts.

The The existence of negative consequences from the use of criminal sanctions demonstrates that the objective of criminal sanctions in the form of jail in the case of children who abuse narcotics is ineffective. The court should use suitable criminal sanctions in his decision to protect children from the bad effects of criminal sanctions in prison, which might interfere with the fulfillment of the aim of sentencing children, which is to protect children's 
rights and best interests children to ensure the protection of children in carrying out their criminal threats. Another reason is that the imposition of imprisonment will cause negative impacts and losses, especially for child convicts. As for the effects of imposing a criminal deprivation of liberty on children, among others, Children will be separated from their families, resulting in family relationship disorders such as a lack of education, direction, and positive guidance from parents to child convicts, children becoming more knowledgeable about crime due to the influence obtained from other convicts, which allows the convict to study the criminal behavior of other convicts, and the community becoming more knowledgeable about crime.

Following the concept of restorative justice, the perpetrator is still punished, but It is carried out as part of the educational process rather than as a form of punishment. Discipline in the educational process should not be used as a means of moral enlightenment or maturity as a full person, but rather as a method of reducing the spirit of life, let alone killing a child's future. Examples of cases of children as drug users are in the Rantauprapat District Court Decision Number 435/Pid.B/2014/PN Rap. Based on the facts revealed in court, the The defendant, a 17-year-old boy, was caught smoking meth from a methamphetamine bong on a table near the television. The defendant did not have permission to take methamphetamine, which is a Category I narcotic. The defendant had been legally and convincingly proven guilty of "participating in and without the right to abuse narcotics Category I for oneself" as defined in Article 127 paragraph (1) letter an of the Law of the Republic of Indonesia Number 35 of 2009 concerning Narcotics, according to the judge. The offender was sentenced to 8 (eight) months in prison by the judge.

In the decision, the judge considered mitigating factors for the defendant, namely:

a. The defendant regretted his actions and promised not to do it again in the future.

b. The defendant was polite and admitted his actions frankly to facilitate the trial.

c. The defendant is still a teenager and can still be expected to improve himself and his behavior in the future.

Based on the explanation above about what crimes can be imposed on children using narcotics according to the Number 11 of 2012 of the Republic of Indonesia about the Juvenile Criminal Justice System and Number 35 of 2009 of the Republic of Indonesia concerning Narcotics.

\subsection{Implementation of Diversion for Children Who Use Narcotics as Well as Victims in the Concept of Restorative Justice}

If based on the following: (1) Restorative justice focuses too much on rehabilitation; (2) Restorative justice condones violence, especially against women and child victims; (3) Contrary to the principle of open public justice and legal protection through the utilization of private forums and co-optation techniques against participants; (4) Too lenient to crime and overrides public zeal for vengeance; (5) Undermining traditional standards of legal judgment through community justice and informal judgments; (6) Contrary to legal aspirations based on equal treatment of the same case and the certainty and consistency of varying results through a restorative justice process.

For this reason, the following steps are also taken to carry out mitigation: (1) All parties must act voluntarily; (2) Victims must be treated sensitively; (3) The perpetrator of the crime should be endeavored not to use the restorative justice system to protect himself, except to help solve the problem created by his crime; (4) The facilitator must be trusted, unbiased and trained; (5) The facilitator must be flexible to solutions proposed by participants in the 
restorative justice process. the above understanding will be reinforcement of the The importance of restorative justice in the settlement of cases involving children, as well as the need to encourage the application of justice in the juvenile justice system in Indonesia, which has now become the basis of the spirit in the Draft Criminal Code, which among other things changes the paradigm, including: The purpose of punishment "resolving conflicts caused by criminal acts, restoring balance, and bringing a sense of peace to the community; Specifically, criminal arrangements and actions for minors are discussed. Law Number 11 of 2012 addressing the Juvenile Justice System, in addition to the Draft Criminal Code, has placed diversion and restoration justice activities.

Furthermore, specific attention to the restorative justice process among teenagers is necessary since there are important concerns that demand the active participation of the community, perpetrators, and victims of crime, as well as impacted districts, in the restorative justice process. A fundamental balance approach must also be taken, with the first step being imposing sanctions based on responsibility to recover victims' losses as a result of criminal acts; the second step being perpetrator rehabilitation and reintegration; and the third step being the strengthening of the public safety and security system.

Because all three are judicial clients, a change away from the punitive and retributive "juvenile justice system," which stresses the objective of nurturing criminals who only fail, and toward a more balanced approach between perpetrators, victims, and the community, is quite rational. Isolating offenders will destroy the "community bond," increasing criminality. The urge to be owned, cared for, and not alone is a natural part of adolescence. Adolescents have significant attachments to certain environments, such as school, work, religion, and leisure activities, which they express via clothes, music, and language.

More criminal acts and violence will follow from breaking the relationship with the environment owing to suspicion, worry, or terror of adolescent offenders, along with a corrective approach to criminalizing and enforcing behaviors. We'll need a new "juvenile justice" system with a mission (paradigm shift) that is more productive, responsive, and successful in promoting three interests (perpetrators, victims, and society). The three will have "shared responsibility" for strengthening community development and bridging the gap between youth and culture.

There is a spirit to correct the retributive or retaliatory approach or philosophy in the criminal justice system (medical model), which focuses entirely on the criminal justice system's three (three) needs, namely, the need to punish criminal acts, the need to assist criminals in rehabilitation, and the need to increase security. Public. A fourth need in restorative justice is to repair or restore losses to victims of crime and the community as much as feasible.

Then the recognition of the limitations of criminal sanctions and actions against perpetrators (the limits of treatment and punishment) focuses more on the best interests of the perpetrators, paying less attention to the consequences of criminal acts within the framework of public security and crime victims. The disciplinary approach, especially to children with the concept of crime and action, is often inaccurate and incomplete. There happens because the correctional system is one-dimensional ad hoc insight and has excluded or not involved the "clients" or "customers" of juvenile justice, namely the loss of the victims and the community. There cannot be overcome by criminal and action against the perpetrator.

The The Balanced Approach, which may suit the needs of the community, must be used by the juvenile justice system.:

a. Punishment based on accountability actions that seek to recover the loss of the victim against the criminal act committed by the perpetrator as a consequence of the crime; 
b. Rehabilitation and reintegration of criminals; and

c. Strengthen public safety and security.

This is an articulation step that connects the interests of the prime 3 (three) customers (clients/customers) of victims, criminals, and the community, as well as the criminal justice system; This Balanced Approach also emphasizes the values associated with each client, such as the importance of accountability (accountability) to victims and the community for; the importance of competency development (competency development) for actors (children) who really are predicted to be better able to integrate with the community after undergoing a therapeutic process than ever; and the value of society safeguard, since this rehabilitative team is capable for prying into the lives of victims and the community (peacefully resolved).

In addition to the involvement of victims, affected communities, and perpetrators, it is necessary to emphasize the importance of professionals who are trained and have unique expertise on adolescent behavior in the juvenile justice process (juvenile justice professionals). Its roles include: facilitating mediation, organizing volunteers, seeking input from victims to determine the nature of the losses suffered to determine restitution, choosing certain places that are valuable to the community if community service obligations must be carried out by perpetrators, developing empathy groups, and victim panels, organize community panels, institutions or committees that discuss with perpetrators for the benefit of victims, communities, and perpetrators, facilitate the process of apologizing by perpetrators to victims and the community, raising awareness of victims, etc.

On the one hand and victims and the On the other hand, the community as a whole must identify answers and return to a pattern of good community relations. As a result, "Empowerment" is the essence of Restorative Justice. The heart of treatment, and so of Restorative Justice, is empowerment. Its success is determined by this empowerment. In the context of Restorative Justice, empowerment refers to a meeting between perpetrators and victims, as well as the community, to discuss and actively engage in the resolution of criminal cases (resolution of the illegal issue). On this premise, Restorative Justice can be defined as a concept that incorporates the principle of contemplation in the resolution of criminal cases.

\section{Conclusion}

The Law of the Republic of Indonesia Number 11 of 2012 regulating the Juvenile Criminal Justice System regulates the criminal penalties for youngsters who use narcotics. Children who use narcotics face a sentence that is half as long as an adult's maximum term. Sanctions Returning to parents/guardians, handing over to someone, receiving treatment in a mental hospital, receiving therapy at LPSK, and being required to attend formal education and training provided by the government or private agencies are all activities imposed on children. Furthermore, the consequences that can be imposed on children include both real and non-real penalties. The most important A warning, a conditional sentence, career training, institution coaching, and jail are all options for youngsters. Simultaneously, additional punishments include the confiscation of profits earned via unlawful conduct and the fulfillment of customary requirements.

Efforts to resolve diversion in narcotics crimes by children are associated with victim protection What is meant by child protection, according to Law Number 35 of 2014 concerning child protection, is all efforts to ensure and protect children and their rights, based on the idea of restorative justice, especially legal guardian. So that they can live, grow, develop, and participate to their full potential while remaining protected from abuse and 
discrimination. Avoiding arrest, custody, or jail for children who commit drug offences; providing justice before a juvenile court that is objective, unbiased, and conducts a trial that is closed to the public; avoiding disclosure of his identity; and aiding with the prosecution parents/guardians and people who the child trusts; and Providing social advocacy;

\section{References}

[1] W. Nugraha and S. Handoyo, "Penerapan Restorative Justice dalam Penanganan dan Penyelesaian Tindak Pidana Narkotika yang Dilakukan oleh Anak di Kota Balikpapan," J. Facto, vol. 6, no. 1, pp. 1-20, 2019, [Online]. Available: http://jurnal.pascasarjana.uniba-bpn.ac.id/index.php/jurnaldefacto/article/view/38.

[2] D. A. R. Dewi and Z. A. Fakrulloh, "The Effectiveness of Criminal Sanctions Against the Narcotics Criminals," 2021, doi: 10.4108/eai.6-3-2021.2306878.

[3] A. Prasetyo, "Diversi Tindak Pidana Narkotika Terhadap Anak (Studi Kasus di Kabupaten Sambas)," J. Nestor Magister Huk., vol. 4, no. 4, 2017.

[4] Imam Subaweh Arifin and Pujiyono, "Konsep Diversi terhadap Anak sebagai Pelaku Tindak Pidana Narkotika di Masa Depan,” Perspekt. Huk., pp. 54-77, 2020, doi: 10.30649/ph.v20i2.20.

[5] E. E. Supriyanto, M. Rachmawati, and F. J. Nugroho, "Transformative Policies and Infrastructure Strengthening Towards the Police Era 4 . 0," J. Bina Praja, vol. 13, pp. 231-243, 2021.

[6] Ciptono, "Penerapan Tindak Pidana Narkotika Terhadap Anak," ADIL Indones. J., vol. 1, no. 1, pp. 51-60, 2019.

[7] N. A. Syaf and S. Suparno, "Police Efforts in Tackling Theft Crimes," 2021, doi: 10.4108/eai.6-3-2021.2306891.

[8] D. Frangki, "ANAK DALAM PERSPEKTIF VIKTIMOLOGI ( STUDI DI POL RES ASAHAN )," Universitas Medan Area, 2018.

[9] D. Dari and U. N. Tahun, "MEKANISME DIVERSI TERHADAP ANAK PECANDU NARKOTIKA,” J. Justiciabelen, vol. 3, no. 2, 2020. 